\title{
A provisão de habitação social como base do projeto urbano: Proposta para o distrito da Barra Funda, São Paulo
}

\section{Housing provision as urban project basis: Proposal for district of Barra Funda, São Paulo}

DOI: $10.46814 / \operatorname{lajdv3n1-031}$

Recebimento dos originais: 30/10/2020

Aceitação para publicação: 23/12/2020

\section{Lucas Alonso Sales}

Mestrando em Migrações pela Faculdade de Ciências Sociais e Humanas da Universidade Nova de Lisboa (NOVA FCSH)

E-mail: alonsosales@gmail.com

\section{Marina Coatti Martorelli}

Pós-graduada em Gestão de Planos e Projetos Urbanos pela Universidade Presbiteriana Mackenzie E-mail: marina.coatti.martorelli@gmail.com

\section{RESUMO}

O presente artigo propõe intervenção em área selecionada no interior da operação urbana Água Branca, no distrito da Barra Funda, São Paulo. Para isso, parte da análise da configuração socioeconômica e urbanística local, traçando diagnóstico que baseia a proposta de reconfiguração de cerca de 130 mil $\mathrm{m}^{2}$. A principal diretriz do projeto é a de prover habitação social para os quase mil moradores de aglomeração subnormal da região, a Favela do Sapo. A oferta de moradia digna resolve a questão habitacional local e permite que sejam trabalhadas outras propostas para a área, quais sejam, expansão na oferta de áreas verdes e provisão de equipamentos de educação e saúde públicas.

Palavras-Chave: habitação social, aglomerados subnormais, operação urbana.

\section{ABSTRACT}

This article proposes intervention in selected area within the urban operation "Água Branca", in the district of Barra Funda, São Paulo. It starts from the analysis of the local socio-economic and urban setting, tracing diagnosis basing the proposed reconfiguration of about $130,000 \mathrm{~m}^{2}$. The main project policy is to provide social housing for almost a thousand residents of a sub-standard cluster, known as "Favela do Sapo". The decent housing supply solves the local housing issue and allows other proposals to be developed into this área: expansion in the supply of green areas and provision of public education and health services.

Keywords: social housing, sub-standard clusters, urban operation.

\section{INTRODUÇÃO}

Em fevereiro de 2015, a Prefeitura Municipal de São Paulo (PMSP), por meio da Secretaria Municipal de Desenvolvimento Urbano (SMDU), lançou concurso público nacional de estudos 
preliminares para plano de urbanização de um setor (nomeado “A1”) da operação urbana Água Branca, no distrito da Barra Funda, zona oeste de São Paulo.

O estudo prévio da região em geral e do instrumento “operação urbana” em particular levaram à reflexão em torno da elaboração de um projeto para a área, dado que o contato com a matéria permite que se analise de forma mais precisa e eficiente o contexto atual do uso e ocupação do solo na região e a forma como vem sendo conduzidas as políticas urbanas, em especial as intervenções realizadas com a venda de solo criado.

A partir deste diagnóstico, é possível elencar prioridades para a região e traçar um plano sólido, consistente e que atenda, de fato, às necessidades locais, de acordo com a função social do solo e da propriedade urbana, conforme defende nossa carta magna, a Constituição Federal brasileira de 1988.

No presente artigo, pretende-se elaborar proposta teórica para intervenção na área, tomando como base para um projeto a provisão de habitação social, isto é, a reconfiguração da região em questão partindo da existência de moradia popular.

\section{BREVE HISTÓRICO DA URBANIZAÇÃO DA BARRA FUNDA}

De acordo com histórico elaborado por Ponciano (2004), a área hoje ocupada pelo distrito da Barra Funda, junto a parcelas dos atuais distritos da Freguesia do Ó e da Casa Verde, tem como primeiro registro oficial de ocupação, em meados do século XIX, a posse de Antônio da Silva Prado, o Barão de Iguape.

Ao final do século XIX, após o loteamento da antiga propriedade, a região passa a ser ocupada por imigrantes italianos, que, ao chegarem ao Brasil, encontram emprego em serrarias e oficinas que atendem elite dos Campos Elíseos, bairro próximo à Barra Funda, então habitado pela elite paulistana.

Data da mesma época a inauguração da Estação Barra Funda da Estrada de Ferro Sorocabana, que ligava o Porto de Santos ao interior do Estado de São Paulo, com o objetivo de escoar a produção de café, principal item da pauta de exportação brasileira.

Com o passar dos anos, a ferrovia, antes destinada ao escoamento de café, passa a contemplar também o transporte de passageiros, o que estimula o crescimento populacional na região, potencializado pelo fim da escravidão e a consequente busca dos escravos libertos por um espaço na cidade.

No início do século XX, a Barra Funda passa a ser servida também por linha de bonde, que a ligava ao Largo São Bento, no centro da cidade.

A infraestrutura de transportes na região, o adensamento populacional e desenvolvimento comercial ali notados atraem investidores da nascente indústria brasileira a se instalar no local, principalmente entre a linha férrea e o rio Tietê. Na década de 1920, chegam à região as indústrias da 
família Matarazzo, que empregam grande parte da população local e simbolizam a nova e crescente vocação industrial brasileira e, principalmente, paulistana.

Poucos anos mais tarde, a crise econômica mundial deflagrada em 1929 abala o ritmo de crescimento das indústrias locais; a elite residente abandona a região (seus casarões viram cortiços); apenas pequenas indústrias artesanais sobrevivem.

Ao passo que as atividades industriais e comerciais diminuem ali, crescem as expressões artísticas e culturais; além de receber residente como Mário de Andrade, a região ganha teatros, clubes recreativos (em especial, o Grupo Carnavalesco Barra Funda, origem da atual escola de samba VaiVai, transferida anos depois para o distrito da Bela Vista), e o clube Palestra Itália (atual Palmeiras), que constrói ali seu estádio de futebol.

Na década de 1970, quando já é evidente o declínio da atividade industrial local, a região recebe expressivos contingentes de migrantes nordestinos. Também nesta época é construído o Terminal Barra Funda, integrando ali os antigos trens com o recém-instalado Metrô de São Paulo e os ônibus municipais, metropolitanos, intermunicipais, interestaduais e até internacionais.

No final do século XX, a região é sede da Rede Record de Televisão, do parque de diversões Playcenter e da Federação Paulista de Futebol. Posteriormente, também é construído na região o Memorial da América Latina, extenso complexo cultural projetado por Oscar Niemeyer.

Diante da observada sucessão de usos da região, nota-se a perda de população residente. Entre os anos 1997 e 2007, quando foram realizadas duas aferições da Pesquisa Origem e Destino do MetrôSP, a população do distrito da Barra Funda caiu de 14 mil para 10 mil habitantes, uma queda de quase $30 \%$ em apenas dez anos.

De acordo com o Censo Demográfico realizado em 2010 pelo IBGE, porém, o mesmo território superava a marca de 15 mil habitantes, um crescimento populacional expressivo (mais de $40 \%$ em apenas três anos), alcançando a densidade de mais de 2.500 habitantes por quilômetro quadrado.

$\mathrm{O}$ adensamento populacional realizado em curto espaço de tempo atende a uma das diretrizes da lei que regula a operação urbana Água Branca, conforme será analisado a seguir.

\section{A VIGÊNCIA DA OPERAÇÃO URBANA ÁGUA BRANCA}

A lei municipal no 11.774, de 18 de maio de 1995, estabeleceu a operação urbana "Água Branca" em uma área de aproximadamente 540 hectares, perfazendo quase toda a área do distrito paulistano da Barra Funda, conforme ilustra o mapa a seguir. 


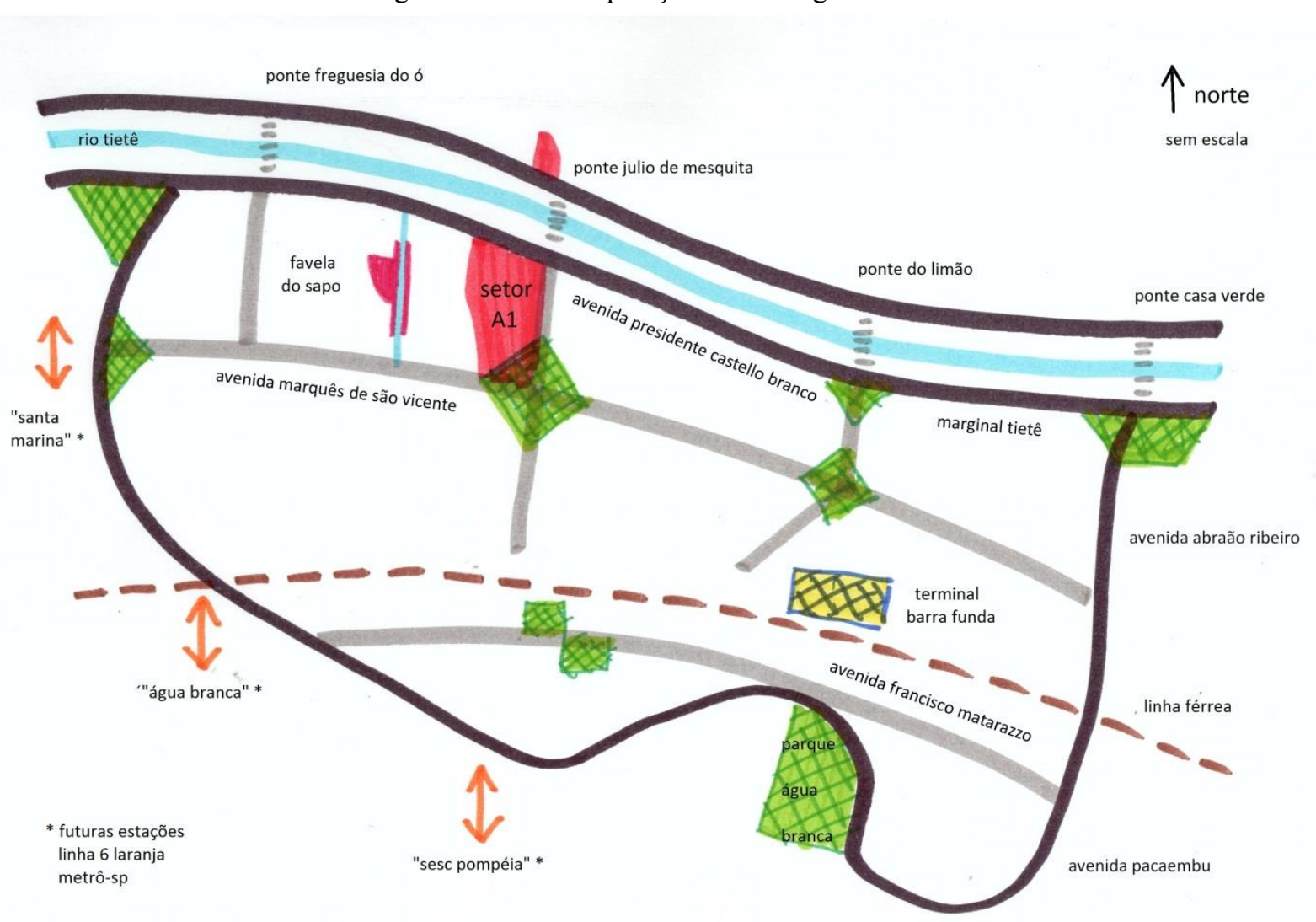

Fonte: elaborado pelo autor.

A operação urbana Água Branca foi concebida com o objetivo de criar uma nova centralidade na cidade de São Paulo, como um contraponto às centralidades paulistanas do Centro e das Avenidas Paulista, Faria Lima, Berrini e Nações Unidas - áreas dotadas de infraestrutura, onde se concentram os mais diversos serviços públicos e privados; e reverter o baixo adensamento populacional do distrito da Barra Funda.

Para promover o desenvolvimento e adensamento na região, fez-se necessário requalificá-la, perseguindo quatro objetivos gerais: i) promover melhorias em seu sistema viário, principalmente nas ligações de longo percurso, dado que o terminal rodo-metro-ferroviário da Barra Funda satisfaz a necessidade de acessos via transporte público; ii) ofertar equipamentos de interesse social, especialmente habitações, além de escolas e hospitais que atendam ao incremento populacional previsto; iii) implantar espaços públicos de serviços e lazer; e iv) operar melhorias em seu sistema de drenagem, na tentativa de evitar as recorrentes inundações na região, causadas pela impermeabilização do solo e deficiência de redes e galerias para escoamento de águas pluviais.

O programa de obras da operação, descrito na lei supracitada, definia como intervenções prioritárias na região: obras viárias, como extensão e alargamento de ruas e avenidas, ligações viárias, 
passagens em desnível, construção de pontes e pavimentação; parcelamento e arruamento de quadras; alargamento de passeios públicos; implantação de bolsões de estacionamento; elaboração de um programa de drenagem da área e sua posterior execução; desenvolvimento, execução e financiamento de projeto de construção de, no mínimo, 630 unidades habitacionais de interesse social, para a população hoje residente em favelas localizadas no interior do perímetro da operação; e a construção de um edifício, em terreno de propriedade municipal, para uso de entidades de administração direta ou indireta do município.

A fonte de recursos para a execução do processo de requalificação da região, conforme exposto no capítulo anterior, é a venda de solo criado dentro da área em questão. A posição dos estoques consumido e disponível, acumulados até dezembro de 2014, está detalhada na tabela a seguir, baseada em dados disponibilizados pela PMSP (2015).

Tabela 1 - Estoque de áreas de potencial construtivo da operação Água Branca, em m²

\begin{tabular}{lrrrr}
\hline Uso & Limite (A) & Consumido (B) & $\begin{array}{r}\text { Disponível } \\
(\mathrm{A}-\mathrm{B})\end{array}$ & \% consumida \\
\hline Residencial & $300.000,00$ & $299.997,67$ & 2,33 & 99,9 \\
Não residencial & $900.000,00$ & $511.788,38$ & $388.211,62$ & 56,9 \\
\hline TOTAL & $1.200 .000,00$ & $811.786,05$ & $388.213,95$ & 67,7 \\
\hline \multicolumn{5}{c}{ Fonte: PMSP, 2015. }
\end{tabular}

Nota-se que a demanda por espaço para construção residencial já consumiu praticamente toda a oferta de solo criado para este uso. Já em relação ao uso não residencial, também se observa grande demanda, porém ainda há estoque de potencial construtivo, dado que a oferta foi três vezes maior que a de uso residencial.

A grande demanda observada por estoques de solo criado na Barra Funda levou à revisão da legislação da operação urbana Água Branca e consequente elaboração de nova lei para regulá-la. Aprovada em 07/11/2013, a lei de número 15.893 institui, entre outras pequenas alterações, como inclusão de perímetros de integração à área total de intervenção, uma grande mudança na forma de arrecadação do instrumento.

A partir de então, são comercializados em bolsa de valores títulos que dão direito à construção dentro do potencial adicional ou alteração de uso, os chamados CEPAC (Certificado de Potencial Adicional de Construção), assim como já ocorria nas operações Água Espraiada e Faria Lima, dois sucessos de arrecadação de outorga onerosa propiciados pela intensa demanda do mercado imobiliário.

De acordo com informações publicadas pela Comissão de Valores Mobiliários (CVM) em 2015, o valor do CEPAC da operação urbana Água Branca é de R \$ 1.548,00, podendo chegar a R \$ $1.769,00$. 
A oferta atual é de 1,85 milhões de $\mathrm{m}^{2}$, sendo $73 \%$ para uso residencial e $27 \%$ para uso não residencial. $\mathrm{O}$ acréscimo de estoque de solo criado propiciado pela nova lei é 1,5 vezes maior que o ofertado pela lei anterior, e representará arrecadação ainda maior de recursos vinculados ao distrito da Barra Funda.

Até dezembro de 2014, de acordo com dados divulgados pela Secretaria Municipal de Desenvolvimento Urbano, o total acumulado do arrecadado com a venda de solo criado na região desde o início da operação urbana Água Branca somava quase 680 milhões de reais, dos quais restavam em caixa quase 570 milhões de reais, conforme relata balanço financeiro que segue.

Tabela 2 - Balanço financeiro da operação urbana Água Branca

\begin{tabular}{lcc}
\hline ENTRADAS & $678.252 .095,21$ & $100,0 \%$ \\
\hline Outorga onerosa & $545.269 .386,24$ & $80 \%$ \\
Receita financeira líquida & $132.982 .708,97$ & $20 \%$ \\
\hline SAÍDAS & $-110.949 .029,78$ & $-16 \%$ \\
\hline Obras e serviços & $-74.362 .865,89$ & $-11 \%$ \\
Desapropriação & $-31.719 .137,12$ & $-5 \%$ \\
Taxa de administração & $-4.656 .705,58$ & $-1 \%$ \\
Outras despesas & $-210.321,19$ & $-0 \%$ \\
\hline SALDO EM CAIXA (dezembro/2014) & $567.303 .065,43$ & $84 \%$ \\
\hline \multicolumn{2}{c}{ Fonte: PMSP, 2015. }
\end{tabular}

A perspectiva, portanto, é a de que o aumento da oferta de solo criado multiplicado pelo expressivo valor do CEPAC que o comercializa gerem arrecadação acumulada que atinja a casa dos bilhões de reais, alcançando assim o patamar arrecadado pelas operações urbanas Água Espraiada e Faria Lima, localizadas no vetor sudoeste da capital paulistana, região de grande demanda por parte do mercado imobiliário.

A expressividade dos recursos não garante por si só o cumprimento das intervenções determinadas em lei, mas demonstra a capacidade de fazê-lo, ou seja, é economicamente possível que se requalifique o perímetro urbano em questão e que se incluam as parcelas de menor renda da população paulistana entre os beneficiários destes investimentos.

\section{Diagnóstico: CONTEXTO ATUAL DA CONFIGURAÇÃO URBANA E SOCIOECONÔMICA LOCAL}

Conforme sugere a própria legislação referente à operação urbana Água Branca, a primeira necessidade evidente na região é a de solução da questão habitacional; em especial, relacionada aos habitantes da Favela do Sapo, aglomeração subnormal presente no entorno do córrego Água Branca, retratada nas imagens a seguir. 


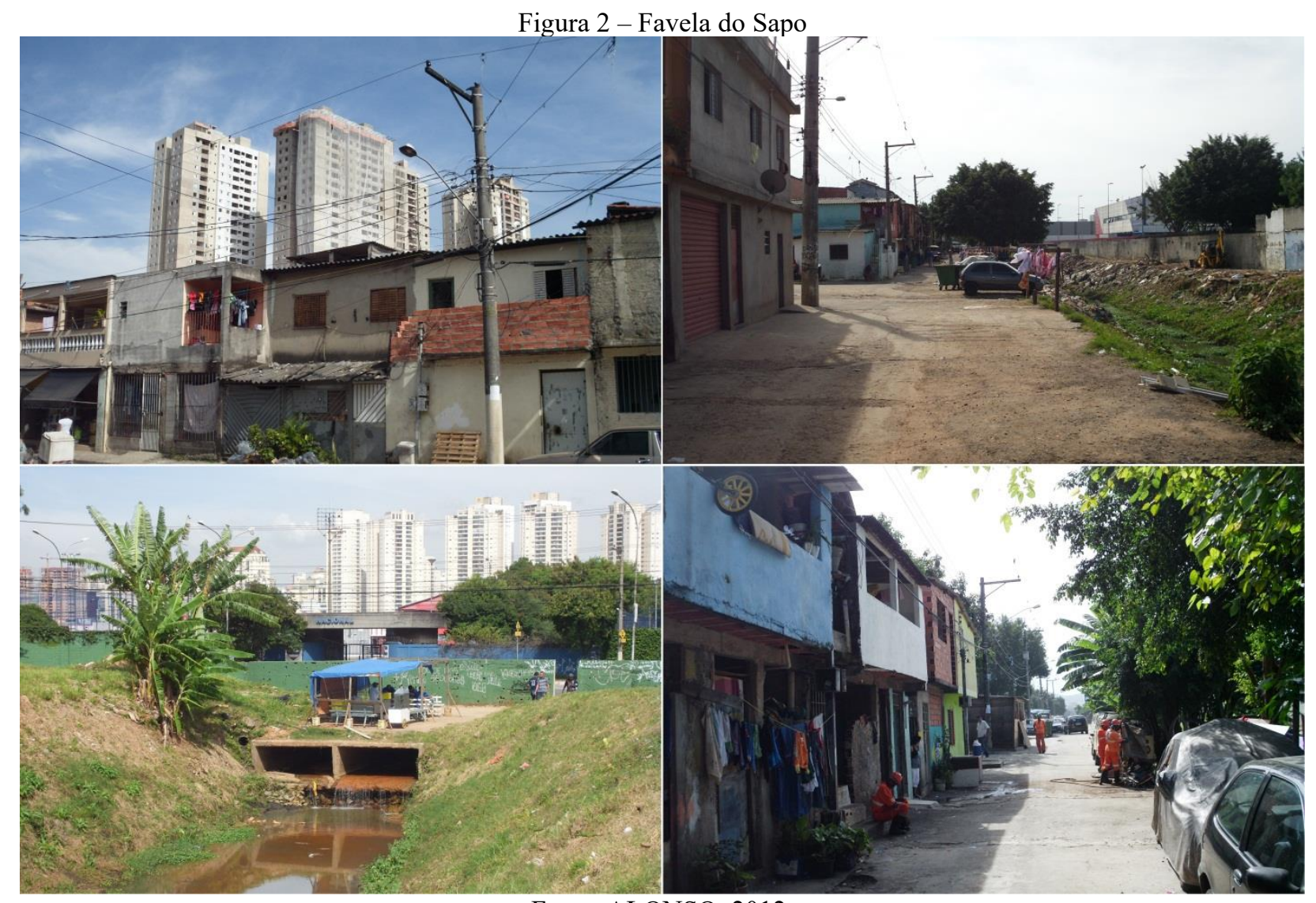

Fonte: ALONSO, 2012.

De acordo com o Censo Demográfico dos Aglomerados Subnormais realizado em 2010 pelo IBGE (2011), são 987 habitantes divididos em 265 domicílios em condições subnormais de ocupação, de coleta de esgoto e lixo e de abastecimento de água e luz, conforme ilustram os gráficos abaixo. 
Quadro de gráficos - Dados socioeconômicos do setor censitário Água Branca (Favela do Sapo)

Condição de ocupação

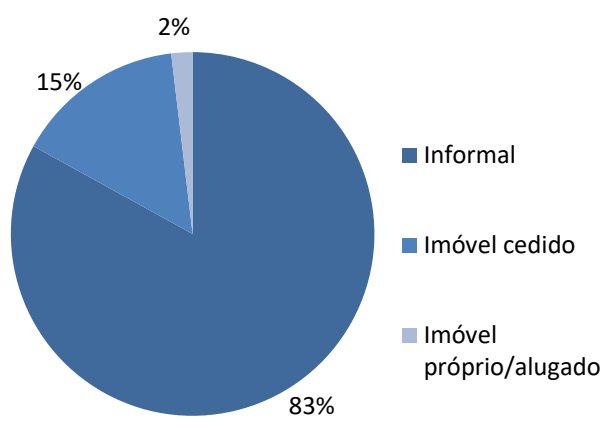

Coleta de esgoto

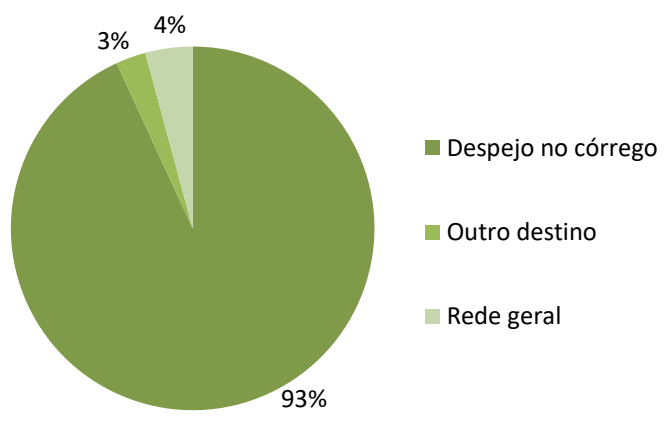

Fonte de abastecimento de água

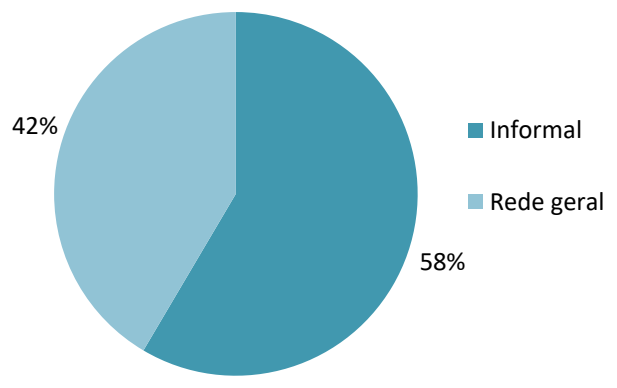

Domicílio com banheiro exclusivo

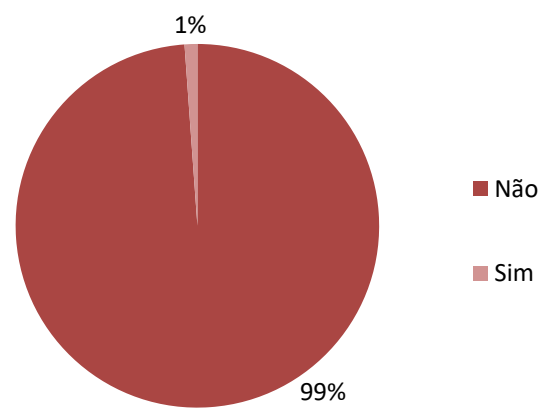

Forma de coleta de lixo

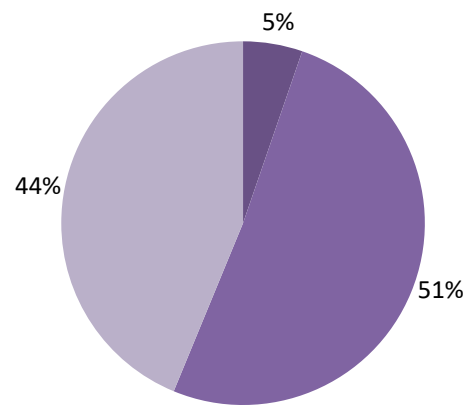

Descarte no

córrego

- Caçamba

Serviço de limpeza
Fonte de energia elétrica

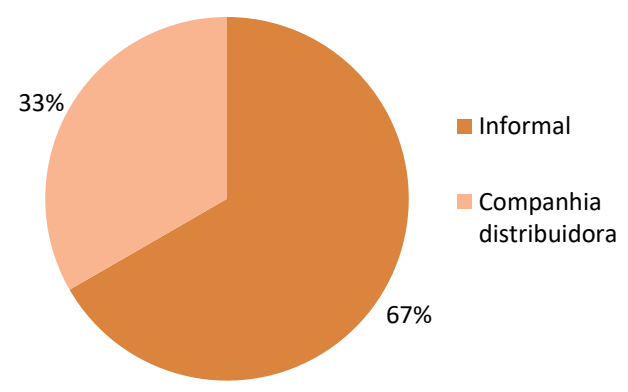

Fonte: elaborado pelo autor, com base em dados do IBGE, 2011.

Os dados do IBGE evidenciam as condições precárias de moradia às quais estão expostos os moradores da região. A maioria dos domicílios é ocupada informalmente (83\%); quase nenhum conta com banheiro exclusivo; e mais da metade não está ligada às redes oficiais de abastecimento de água ou de fornecimento de energia elétrica. Diante do quadro observado, faz-se primordial a provisão de habitação de interesse social, ou seja, a garantia de moradia digna a estas quase mil pessoas.

Por outro lado, para além da solução do déficit habitacional gerado pela Favela do Sapo, a construção de habitações de interesse social possibilita também a reestruturação urbana e ambiental da região. 
Atualmente, grande parte do lixo e do esgoto gerados na Favela do Sapo são descartados no córrego Água Branca, o que significa que a informalidade e precariedade na habitação causa impacto negativo na região e na cidade como um todo, qual seja, a poluição de bacias fluviais.

A presença de moradias irregulares nas margens do córrego também causa impacto negativo, não só para os moradores em situação de risco, mas também por configurarem obstáculo para a solução de questões de drenagem e renaturalização do córrego Água Branca, o que resolveria problemas causados pelas frequentes enchentes na região, além de devolver à cidade áreas verdes e rios menos poluídos.

Portanto, a transferência dos quase mil habitantes da Favela do Sapo para habitações de interesse social na região (e não em Cidade Tiradentes, para onde desapropriados das favelas paulistanas costumam ser relocados) resolve não só o problema principal que se encontra neste setor censitário, a demanda por moradia digna, mas abre espaço para que se solucionem questões de drenagem e ambientais, também urgentes no distrito da Barra Funda.

A análise do perfil da população da Favela do Sapo traz à tona mais uma questão, que, assim como a provisão de habitação e a reestruturação urbana e ambiental da região, deve figurar entre as premissas de qualquer que seja o projeto de intervenção no setor definido pela Prefeitura de São Paulo.

A pirâmide etária deste setor censitário, exposta abaixo, aponta para o fato de que $45 \%$ da população local tem menos de 20 anos, ou seja, um contingente de quase 500 crianças e adolescentes submetidos a condições subnormais de habitação.

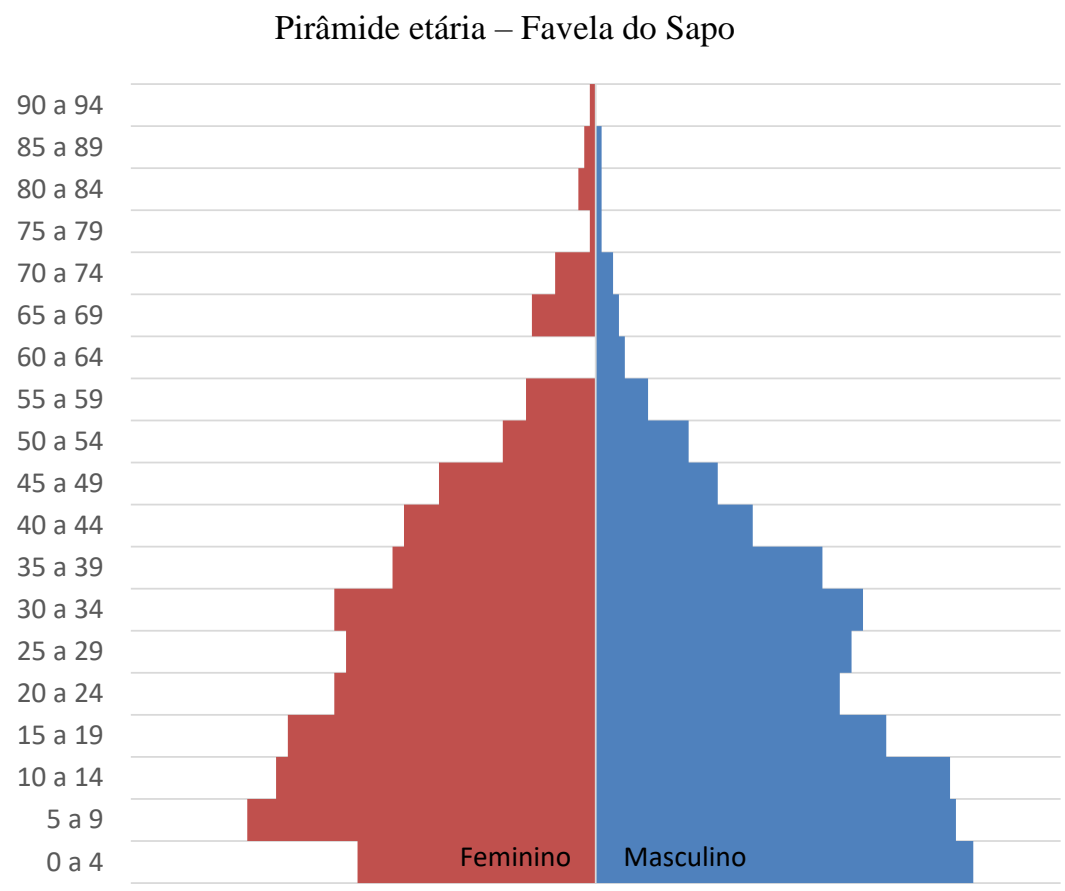

Fonte: elaborado pelo autor, com base em dados do IBGE, 2011. 
A presença de tantos habitantes em idade escolar por si só justifica a implantação de equipamentos públicos de educação em diversos níveis: infantil, fundamental, média e profissional. Porém, a existência destes serviços na região beneficia não só a seus habitantes, mas aos residentes e empregados na região e adjacências em especial, e aos paulistanos de forma geral, dada a necessidade de maior quantidade, além da qualidade, de equipamentos de educação pública.

\section{A PROPOSTA DE INTERVENÇÃO}

Com base no diagnóstico realizado na seção anterior, consideram-se três prioridades para intervenção na região:

1. A provisão de habitação de interesse social que inclua os 987 habitantes da Favela do Sapo e, se for possível, outros cidadãos paulistanos em situação de habitação subnormal;

2. a reestruturação urbana e ambiental da área remanescente da Favela do Sapo, quando forem relocados seus habitantes atuais, e de outros espaços adjacentes; e

3. a provisão de equipamentos de educação pública que atendam à grande população de crianças e adolescentes da Favela do Sapo, em especial, e do município de São Paulo, em geral.

Estas prioridades estão em total acordo com as diretrizes estabelecidas pelas leis que regulam a operação urbana vigente na região. Tanto a lei 11.774/1995 quanto sua substituta 15.893/2013 preveem que os recursos arrecadados pela venda de solo criado na região sejam invertidos em habitação de interesse social, obras de drenagem e recuperação de áreas verdes, e implantação de equipamentos públicos, entre outras diretrizes, com as quais corroboram os dados do IBGE anteriormente expostos.

Seguindo a mesma lógica, o concurso de estudo preliminar para urbanização da área, lançado em 2015 pela Prefeitura de São Paulo, sugere para o "setor A1" intervenções pontuais: a provisão de habitação social que abrigue a população local em condições subnormais de moradia; de parques e outras áreas verdes de fruição pública; e de um centro de educação infantil, entre outras, como uma unidade básica de saúde.

O mapa a seguir, divulgado na página do concurso lançado pela Prefeitura de São Paulo, define a reestruturação viária a ser realizada no setor A1 e os espaços onde devem ser implantados os equipamentos citados, que somam $135.274 \mathrm{~m}^{2}$. 
Figura 3 - Mapa de premissas do concurso para o setor A1

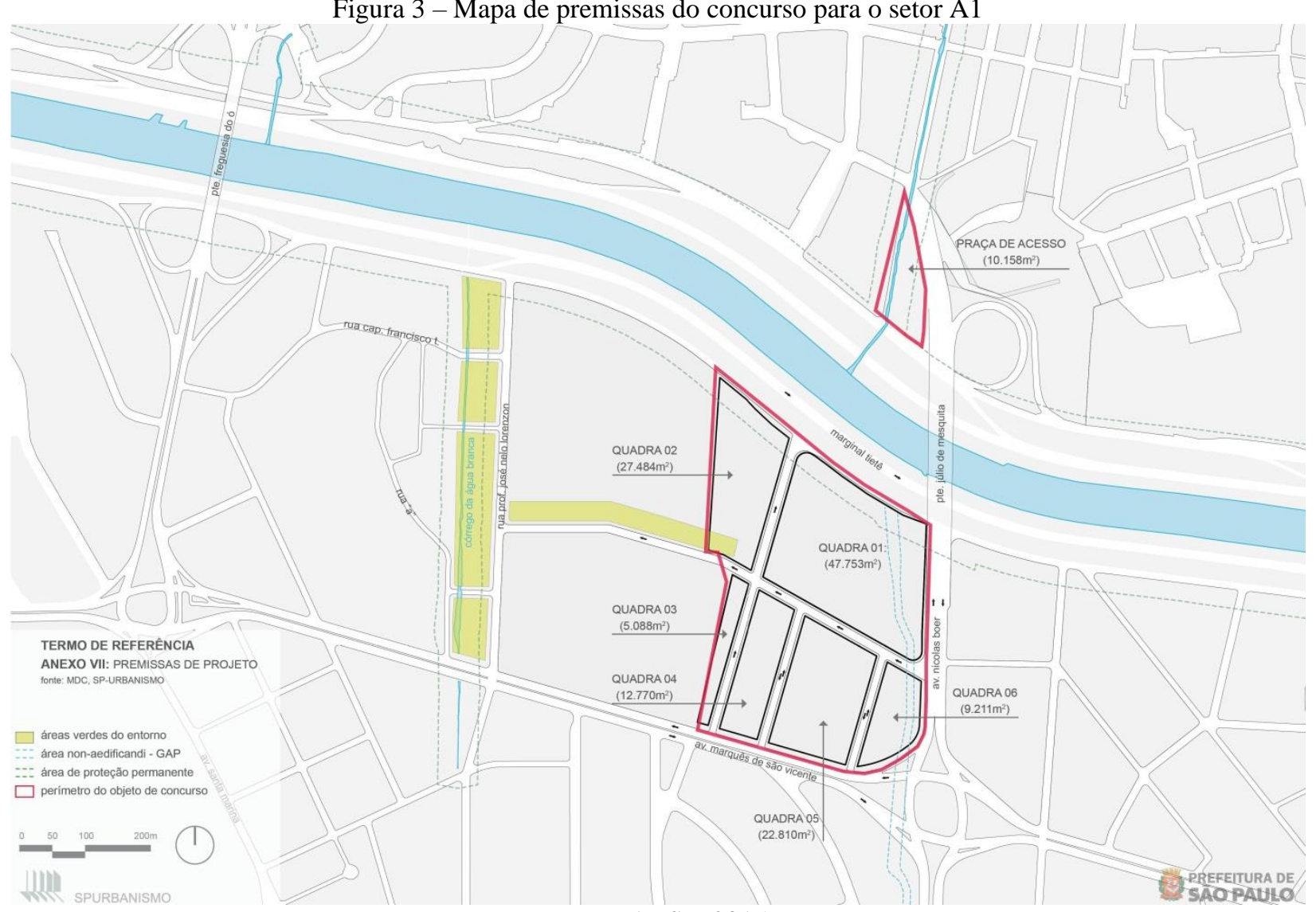

Fonte: IABSP, 2015.

\subsection{HABITAÇÃO SOCIAL}

Segundo a Lei 15.893/2013, o número mínimo de unidades de habitação de interesse social necessárias dentro do perímetro da operação é de 630 domicílios, enquanto são 265 os domicílios em condições subnormais presentes na Favela do Sapo.

A proposta de provisão de habitação social para o setor A1 é a de contemplar os quase mil habitantes da comunidade citada com moradias dignas e, assim, cumprir mais de um terço da proposta básica de unidades habitacionais para a operação urbana Água Branca.

A inspiração para a proposta de provisão de habitação social na região vem de projeto realizado no perímetro da operação urbana Água Espraiada: o Conjunto Habitacional Jardim Edite, idealizado para receber os moradores de comunidade homônima, localizada no distrito Itaim Bibi, sudoeste da capital paulistana.

O projeto articula 252 unidades habitacionais de cerca de $50 \mathrm{~m}^{2}$, divididas em 4 edifícios de apartamentos, a três equipamentos públicos: uma creche, uma unidade básica de saúde (UBS) e um restaurante-escola, ocupando um total de $25.700 \mathrm{~m}^{2}$ da região citada. 
Figura 4 - Conjunto Habitacional Jardim Edite (plantas)
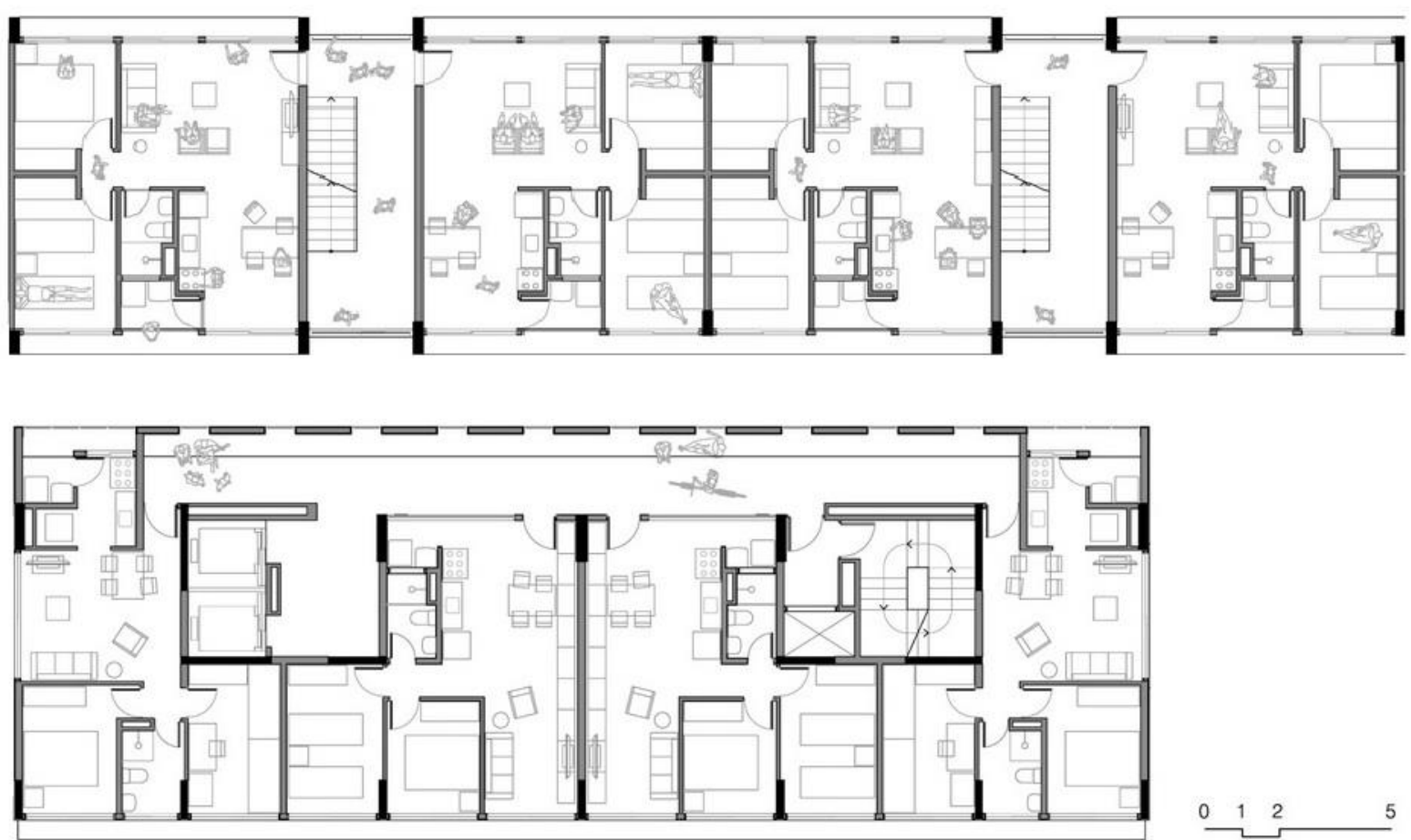

$0 \quad 1$

Fonte: ARCHDAILY, 2013.

A ideia serve de modelo para a futura intervenção na região da Barra Funda por diversos fatores. Em primeiro lugar, seus parâmetros também atendem ao exigido pelo concurso para estudo de urbanização da Prefeitura de São Paulo, ao articular habitação social e equipamentos públicos, atendendo ao mesmo tempo as necessidades dos moradores de aglomeração subnormal de moradia digna e de serviços públicos básicos de educação e saúde em um mesmo espaço.

Figura 5 - Conjunto Habitacional Jardim Edite (corte longitudinal)

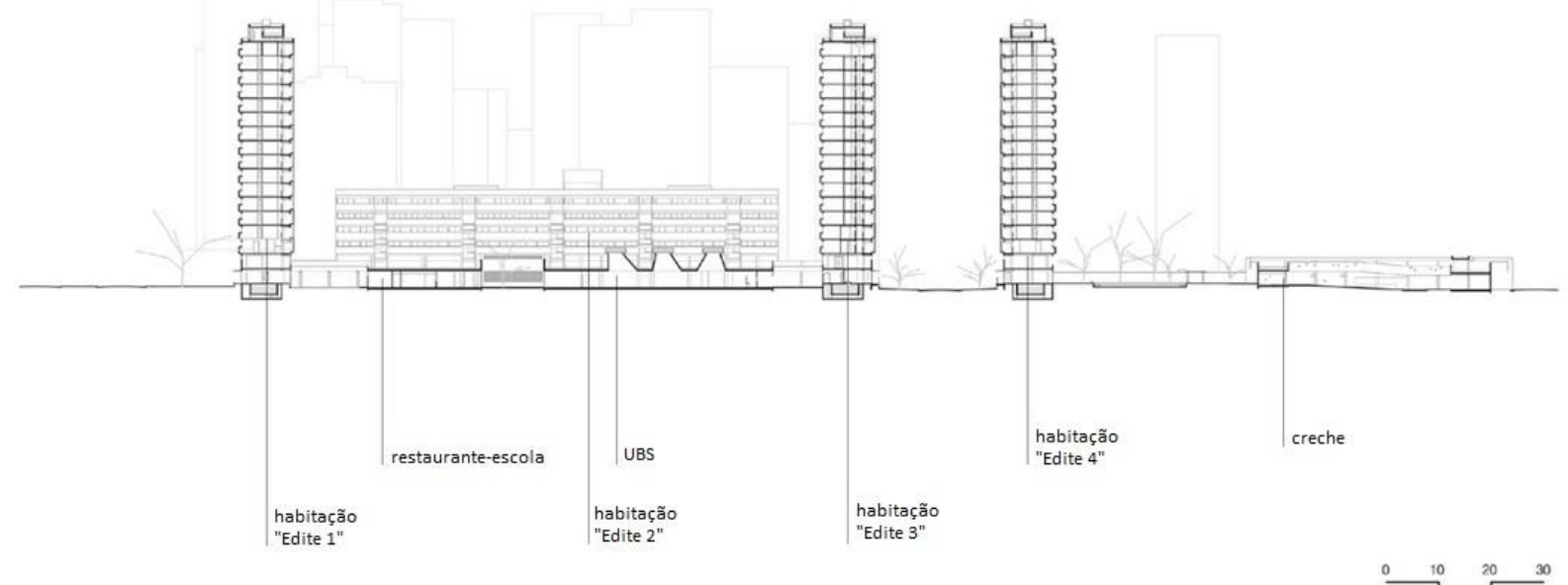

Fonte: ARCHDAILY, 2013, adaptado pelo autor. 
Em segundo lugar, o conjunto habitacional Jardim Edite difere do que tem sido produzido na habitação social no Brasil, pois apresenta maior verticalização dos edifícios. Desta forma, o projeto foge ao "padrão" e quebra o paradigma comum de unidades habitacionais restritas a cinco andares de altura e sem elevadores.

O conjunto também se destaca no ramo da habitação social pela sua qualidade arquitetônica e estética, pois se encaixa de forma mais harmônica à morfologia urbana local, tecendo-se relação entre a obra arquitetônica e o ambiente observado em seu entorno (Nascimento e Cruz, 2021, p. 47), em uma região onde o padrão de construção é vertical e a venda de solo criado permite que se atinjam altos coeficientes de potencial construtivo.

Figura 6 - Conjunto Habitacional Jardim Edite (vista da Ponte Estaiada)

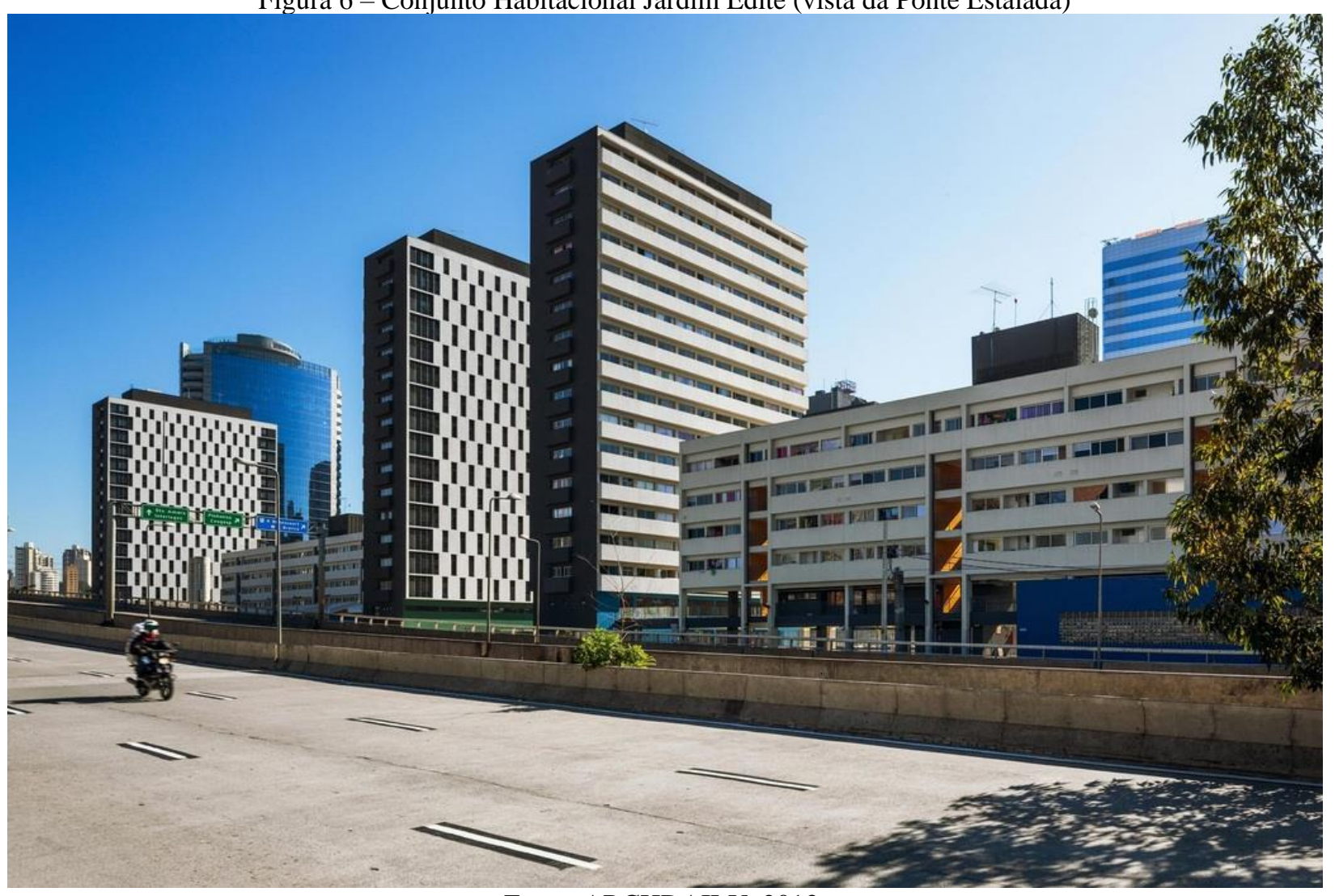

Fonte: ARCHDAILY, 2013.

Partindo do mesmo conceito do projeto do Jardim Edite, a implantação de edifícios de habitação social no setor A1 da operação urbana Água Branca deve se adaptar à morfologia local.

Dada a oferta de $93 \mathrm{mil} \mathrm{m}^{2}$, é possível que se instale, assim como na ideia que os inspira, quatro ou mais edifícios residenciais nos $22 \mathrm{mil} \mathrm{m}^{2}$ da Quadra 05 e nos $9 \mathrm{mil} \mathrm{m}^{2}$ da Quadra 06, espaço pouco maior do que o ocupado pelos cinco edifícios de usos residencial e não residencial na região da 
operação urbana Água Espraiada, o que sugere que ainda sobre espaço para áreas de lazer e convivência do novo conjunto residencial, dado que os demais equipamentos, de usos não residenciais, também contemplados neste projeto, deverão ocupar as quadras vizinhas.

Também é possível que se ocupe as áreas térreas dos edifícios com uso comercial, integrando serviços diversos à região, a serem usufruídos tanto pela população residente quanto pela flutuante, que estuda, trabalha ou frequenta o local por outros motivos.

É importante ressaltar que, apesar de a inspiração para intervenção no setor A1 vir de um projeto semelhante em relação às diretrizes básicas e equivalente tanto nas dimensões da implantação e quanto no número de unidades habitacionais, cada comunidade tem sua especificidade e necessidades distintas, o que sugere estudo mais aprofundado para a intervenção e diálogo junto às associações e sindicatos atuantes na região.

\section{2 ÁREAS VERDES}

A relocação dos moradores da comunidade da favela do Sapo para um conjunto habitacional a ser criado dentro do setor A1, objeto deste estudo, liberaria extensa área na margem oeste do córrego Água Branca. A desocupação da margem do córrego permite que sua renaturalização, e a área remanescente da Favela do Sapo pode compor, junto ao córrego, nova área verde para o perímetro em questão.

A existência prevista pela Prefeitura de São Paulo de um "corredor verde" ligando a área do córrego Água Branca ao "setor A1" sugere que se implante, na Quadra 02, de 27 mil m², um parque conectado ao córrego através deste corredor, conforme ilustra o mapa a seguir, das premissas gerais do projeto em questão, quais sejam, as áreas verdes previstas e as propostas, a reconfiguração viária local e as demais áreas do setor, passíveis de edificação. 
Figura 7 - Área ocupada pela Favela do Sapo

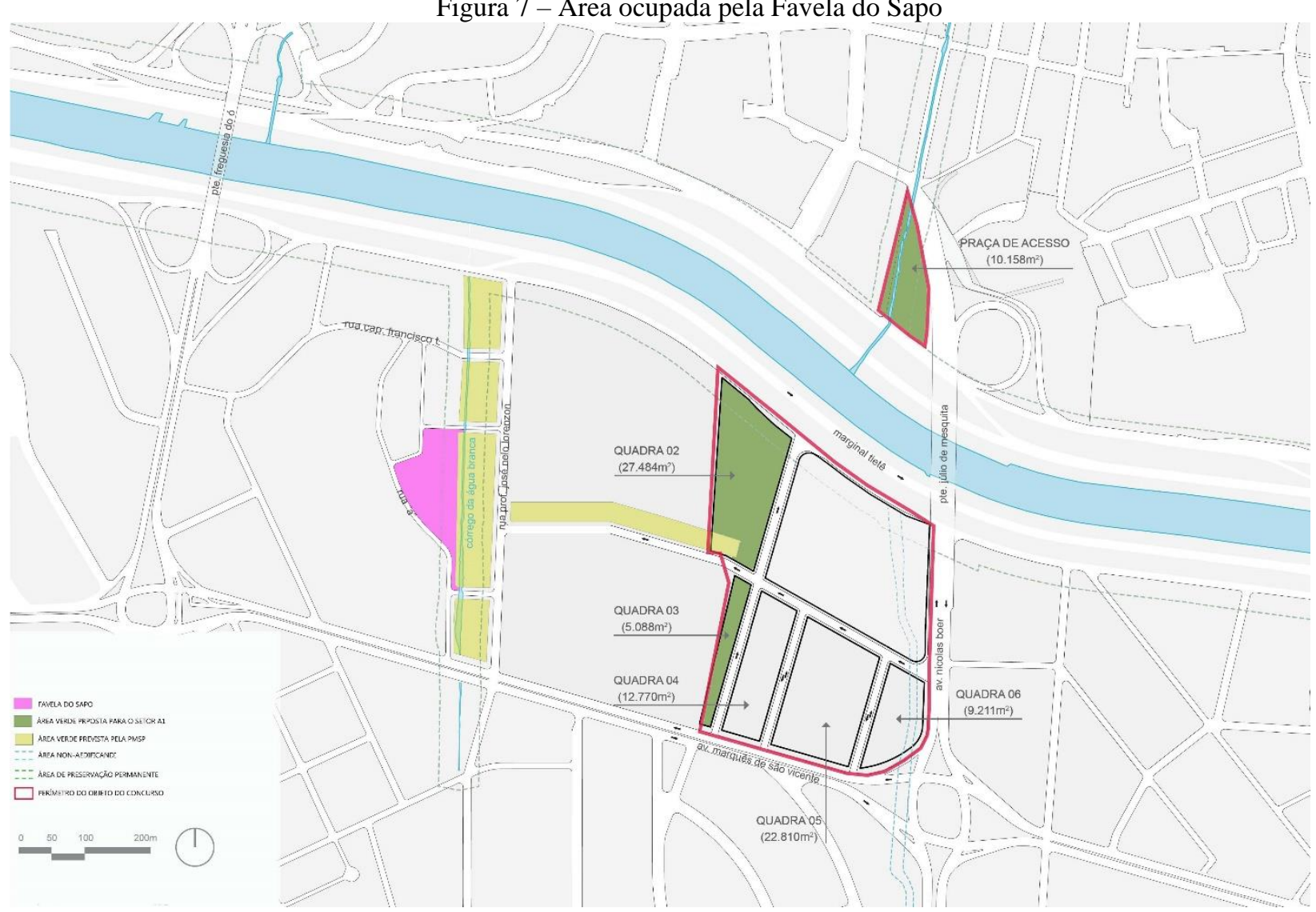

Fonte: elaborado pelos autores, com base em imagens de IBGE, 2011.

A extensão de áreas verdes para a Quadra 03, com área de 5 mil m² e dimensões menos atrativas para edificações em geral, formaria um "H" verde no centro do perímetro da operação urbana Água Branca, um grande parque de formas lineares, aumentando em $32 \mathrm{mil} \mathrm{m}^{2}$ a oferta de áreas verdes na região.

Por fim, a chamada "praça de acesso", área de $10 \mathrm{mil} \mathrm{m}^{2}$ localizada do outro lado do rio Tietê, por onde passa ramal do córrego Água Branca, deve também ser destinada ao aumento da oferta de áreas verdes, dado que a área, parte do distrito do Limão, também conta com poucas áreas verdes e/ou permeáveis. Seriam, portanto, $42 \mathrm{mil} \mathrm{m}^{2}$ de novas áreas verdes.

\subsection{EQUIPAMENTOS DE EDUCAÇÃO PÚBLICA}

O concurso lançado pela Prefeitura de São Paulo inclui entre os itens obrigatórios a constar do projeto de urbanização do "setor A1" uma creche, item também contemplado pelo projeto já analisado do Conjunto Habitacional Jardim Edite, realizado no perímetro da operação urbana Água Espraiada.

A análise da população local, em especial dos habitantes da Favela do Sapo, aponta para uma grande demanda por serviços públicos de educação, dado que $45 \%$ destes habitantes tem menos de 20 anos. 
Desta forma, o ideal é que o conjunto habitacional esteja articulado a equipamentos de educação básica, quais sejam, uma creche e, neste caso, também uma escola de ensino fundamental e médio, contemplando assim quase quinhentos residentes das margens do córrego Água Branca e também outras crianças e adolescentes residentes na região.

Entre as diretrizes a se cumprir para a participação no concurso de urbanização do setor A1, encontram-se projetos de implantação de modelos de "Centro Educacional Unificado" (CEU), verdadeiros complexos com equipamentos voltados para educação, cultura, esportes e assistência social, destinados a jovens de zero a dezoito anos.

O esquema abaixo ilustra como se divide o espaço que deve atender os quase quinhentos jovens habitantes da comunidade Favela do Sapo.

Figura 8 - Organização do espaço dos Centros Educacionais Unificados (CEU)

PROGRAMA DENECESSIDADES

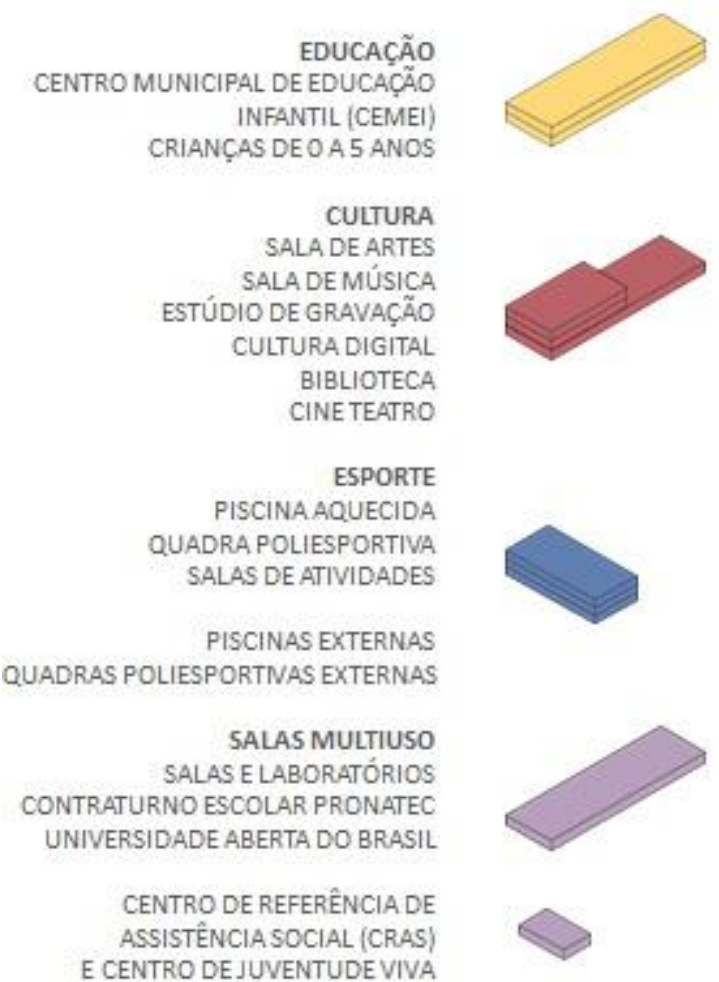

ARRANJOS PARALELOS

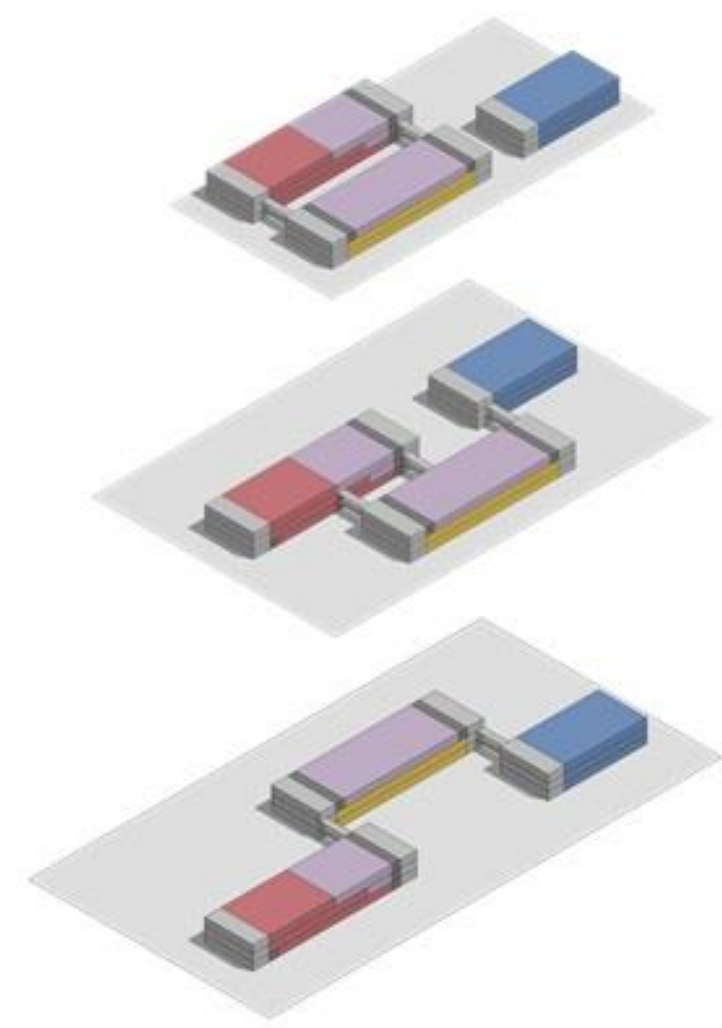

Fonte: IABSP, 2015.

Os projetos de outros CEUs a serem realizados na cidade de São Paulo ocupam entre 11 e 13 mil m², razão pela qual sua implantação pode se dar na Quadra 04, de $12 \mathrm{mil} \mathrm{m}^{2}$ de área.

As imagens a seguir ilustram a implantação do CEU no Parque do Carmo, mostrando a área onde deve ser implantado à esquerda e a simulação da edificação à direita. 
Figura 9 - Implantação do CEU Parque do Carmo

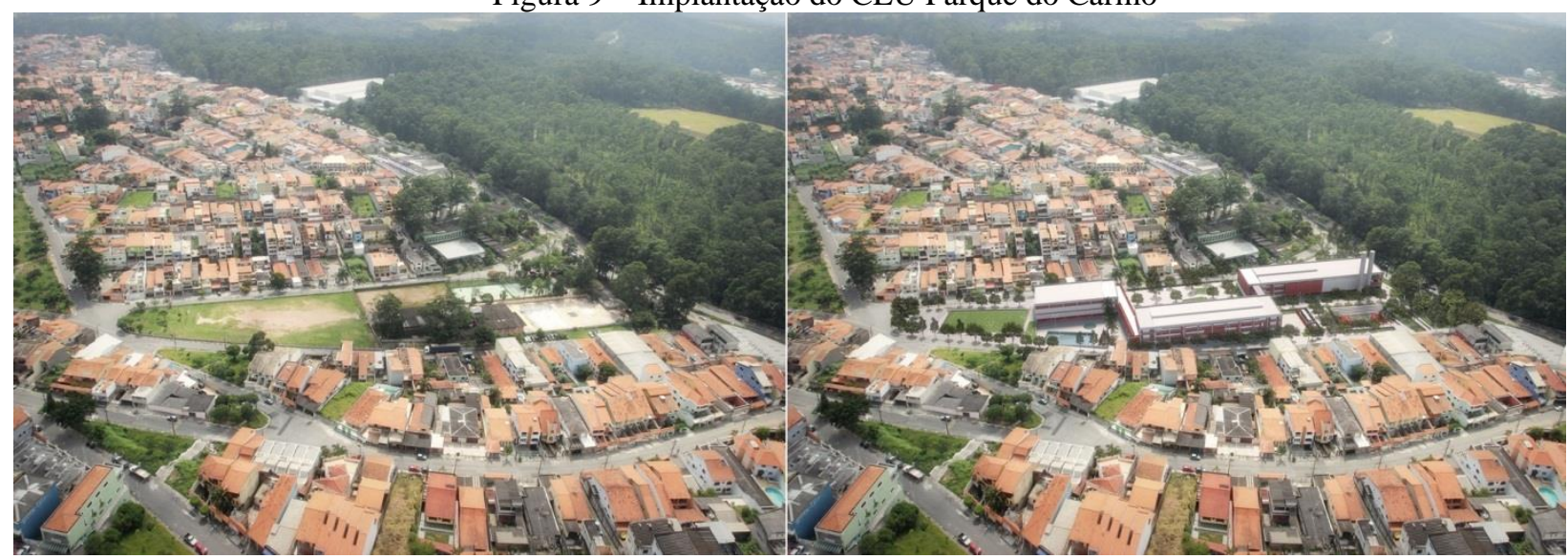

Fonte: IABSP, 2015.

\subsection{DEMAIS POSSIBILIDADES PARA O SETOR A1}

As ideias de intervenção para o setor A1 até aqui elencadas ocuparam, com folga, 46 mil m² dos 135 mil m² disponíveis, o que deixa margem para a concepção de outros projetos para a região.

A Quadra 01, área passível de receber estes novos projetos, tem $47 \mathrm{mil} \mathrm{m}^{2}$ de área bruta, porém, pode-se edificar em cerca de dois terços de seu espaço, ou seja, em pouco mais de $30 \mathrm{mil} \mathrm{m}^{2}$.

A quarta prioridade elencada pelo concurso, e presente no corpo das leis que regulam a operação urbana Água Branca, é a de implantação de uma unidade básica de saúde (UBS). A necessidade de equipamentos de saúde pública na região é justificada pela distância dos principais hospitais públicos e ausência de equipamentos como uma UBS.

Porém, a grande oferta de espaço e qualidade da localização do setor A1 levam à reflexão acerca da expansão da ocupação deste espaço com equipamentos de saúde pública, que estejam integrados também à realidade constatada ao se estudar a população e uso do solo na Barra Funda.

Mais uma vez, o expressivo número de habitantes jovens na região sugere a implantação de novos equipamentos ligados à educação, e, neste caso, pode-se unir a demanda por educação e saúde ao se investir em centros de educação técnica em profissões ligadas à saúde, como enfermagem, nutrição etc.

A inexistência de ETECs (Escolas Técnicas Estaduais) ligadas à área da saúde na zona oeste de são Paulo justifica que ali seja implantada nova escola, integrada à já recomendada UBS, onde os alunos teriam oportunidades de estágio e laboratório.

A implantação de uma ETEC e de uma UBS em cerca de $10 \mathrm{mil} \mathrm{m}^{2}$ da Quadra 01 ainda deixaria cerca de 20 mil $\mathrm{m}^{2}$ remanescentes, que permitem que se prossiga na busca por novos empreendimentos locais que supram as necessidades locais e integrem a região à cidade de São Paulo.

A futura Linha 6 (laranja) do Metrô de São Paulo, prevista pela empresa e já em processo de licitação, cortará o perímetro da operação urbana Água Branca, que conterá ou estará próximo a três 
das estações da linha: Santa Marina, Água Branca (integrada à Linha 7 da CPTM) e Sesc Pompeia (os nomes das estações são provisórios, sujeitos a alteração por parte da empresa até o prazo de sua construção).

A Linha 6 já é conhecida como a "linha das universidades", dado que seu traçado contempla a vizinhança das principais universidades paulistanas, quais sejam, Mackenzie, FAAP e PUC, entre outras.

A prioridade até aqui dada para equipamentos que atendam à população carente, para equipamentos de educação e de saúde pública levam à concepção de ideia de ocupação destes cerca de 20 mil $\mathrm{m}^{2}$ da Quadra 01 com um novo equipamento que pode integrar benefícios à sociedade e interesses privados em um único espaço.

As principais universidades particulares da capital paulista não contam com cursos de Medicina, ou, se contam, os ofertam em campi fora da cidade de São Paulo. Muitas experiências de articulação entre uma universidade que oferta curso de Medicina e hospitais universitários demonstram que é possível que uma empresa particular possa estar integrada à sociedade que a permeia, atendendo sua população, em especial a mais carente, e fazendo disso uma forma de desenvolver sua própria vocação, como, no caso dos hospitais universitários, podem fazer os alunos em período de residência hospitalar.

A grande oferta de espaço na região, a necessidade evidente de novos equipamentos de saúde pública, a priorização da instalação de equipamentos de educação, e até a chegada da "linha das universidades", levam à ideia de se implantar, no setor A1, campus universitário com oferta de curso de Medicina e hospital universitário integrado, atendendo assim às demandas da população local e integrando futuros médicos à comunidade à qual prestarão seus serviços.

\subsection{NOVA CONFIGURAÇÃO URBANA LOCAL}

A proposta até aqui elaborada se distribui na área do setor A1 da forma ilustrada pelo mapa que segue. 
Figura 10 - Novos usos do solo no setor A1

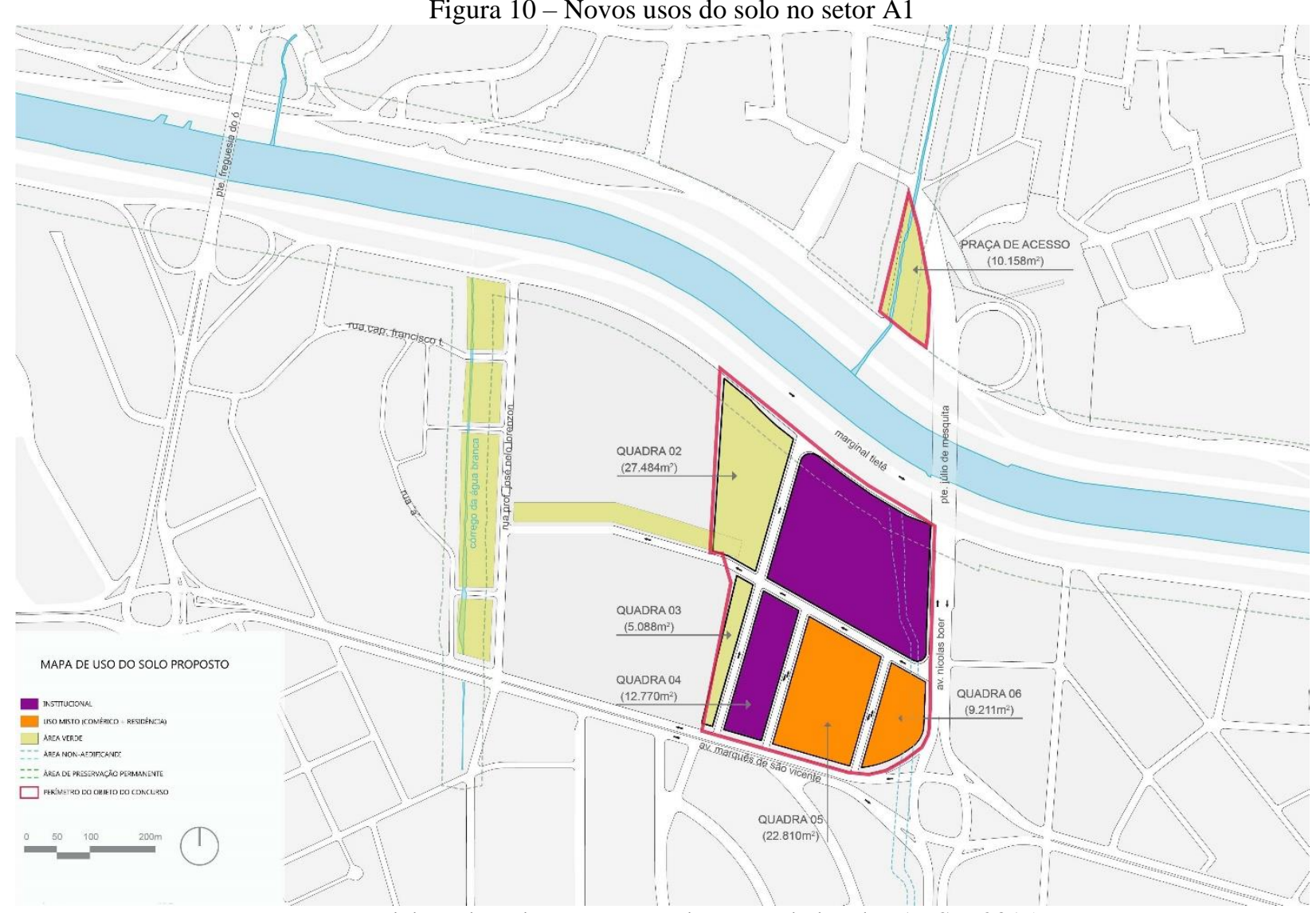

Fonte: elaborado pela autora, com base em dados do IABSP, 2015.

O uso residencial, ou misto, dada a possibilidade de se estabelecer uso comercial no térreo dos edifícios residenciais, ocupa 23,7\% do setor A1. O uso institucional, dividido em equipamentos de educação e saúde públicas, ocupa 44,7\% da mesma área. As novas áreas verdes, integradas às áreas verdes previstas para o entorno e à hidrografia local, ocupam os restantes $31,6 \%$ do solo da região.

\section{CONSIDERAÇÕES FINAIS}

O histórico da urbanização da Barra Funda levou à presente configuração de uma área de infraestrutura consolidada versus baixa densidade populacional e parcelas de solo subutilizadas.

A operação urbana Água Branca propõe reverter este quadro, aproveitando a infraestrutura instalada para estimular a ocupação da região com usos residencial e comercial, através da venda de solo criado.

Os dados da Prefeitura de São Paulo apontam para o sucesso de arrecadação proveniente da venda do solo criado em questão, ou seja, a crescente demanda por potencial construtivo na Barra Funda.

Os recursos então gerados permitem que se resolvam os atuais problemas diagnosticados na região, principalmente a presença de habitações em condições subnormais e a frequência de enchentes, 
além da possibilidade de localizar novos equipamentos e serviços públicos que atendam à população local e das adjacências.

Seguindo o preconizado pelas leis que regulam a operação urbana Água Branca, e com base no levantamento de dados socioeconômicos e urbanos da região, chegou-se a três prioridades básicas para intervenção no setor A1: a provisão de habitação social, o aumento da oferta de áreas verdes e a provisão de equipamentos de educação pública.

A provisão de habitação social configura aqui base do projeto. A relocação dos habitantes da comunidade conhecida como Favela do Sapo, dentro do mesmo perímetro, ou seja, dentro dos limites da operação urbana Água Branca, dá a quase mil paulistanos em condições de habitação subnormal a chance de ter moradia digna em localização privilegiada no contexto paulistano.

Porém, além de resolver a questão habitacional presente na região, esta medida também tem consequências para a gestão ambiental e solução de outros problemas relativos ao distrito da Barra Funda.

O aumento da oferta de áreas verdes nesta região, junto ao córrego renaturalizado, possibilitado pela liberação de área antes ocupada pela comunidade citada, permeabiliza o solo da região, ajudando a mitigar os efeitos de enchentes locais, e permite que se estabeleçam novas formas de fruição da cidade por parte de seus habitantes, além da consequente melhora na qualidade do ar e da água no entorno.

A reconfiguração urbana resultante destas intervenções é completa ao incluir no projeto para região equipamentos de educação pública, atendendo à população de zero a vinte anos que compõe quase metade dos habitantes da comunidade carente encontrada no interior desta operação urbana, integrando assim política habitacional, gestão ambiental e serviços públicos.

Por fim, a implantação de equipamentos de saúde pública completa o atendimento à população carente local, ao passo que a presença de uma universidade altera o perfil da região, estabelecendo relação mais próxima entre médicos e pacientes, além de integrar pessoas de origem e situações distintas em um mesmo espaço.

Em breve, será divulgado o projeto vencedor do concurso de estudo preliminar para urbanização do setor A1 da operação urbana Água Branca. Independente da forma de implantação, espera-se que siga as mesmas diretrizes elencadas neste artigo. 


\section{REFERÊNCIAS BIBLIOGRÁFICAS}

ALONSO, L. 2012. Recuperação de mais-valias fundiárias como recurso para intervenções urbanas: avaliação das Operações Urbanas de São Paulo. São Paulo. Pontifícia Universidade Católica de São Paulo. 40-43, 61-64.

ARCHDAILY. 2013. Conjunto Habitacional do Jardim Edite. Disponível em http://www.archdaily.com.br/br/01-134091/conjunto-habitacional-do-jardim-edite-mmbb-arquitetosmais-h-mais-f-arquitetos_Acesso em 25/03/2015]

COMPANHIA DO METROPOLITANO DE SÃO PAULO (METRÔ-SP). 2008. Pesquisa “Origem e Destino" 2007. Disponível em http://www.metro.sp.gov.br/metro/numeros-pesquisa/pesquisa-origemdestino-2007.aspx \Acesso em 25/03/2015]

IBGE. Censo demográfico. $\quad 2010.2$ Disponível em http://iabsp.org.br/concursoaguabranca/index.php/bases/ [Acesso em 25/03/2015]

Censo demográfico - aglomerados subnormais. 2011. Disponível em http://www.censo2010.ibge.gov.br/agsn/ \Acesso em 25/03/2015]

Instituto dos Arquitetos do Brasil - São Paulo (IABSP). 2015. Concurso Público Nacional e visando qualificar o Plano de Urbanização para o Subsetor A1. Disponível em http://iabsp.org.br/concursoaguabranca/[Acesso em 25/03/2015]

NASCIMENTO, M.; CRUZ, A. 2021. Le Corbusier: Relações entre as obras arquitetônicas e de design do arquiteto e suas observações da natureza. Curitiba: Latin American Journal of Development, v.3, n. 1, p. 43-48, janeiro/fevereiro 2021.

PONCIANO, L. 2004. São Paulo: 450 bairros, 450 anos. São Paulo. SENAC.

PREFEITURA MUNICIPAL DE SÃO PAULO (PMSP). Secretaria Municipal de Desenvolvimento

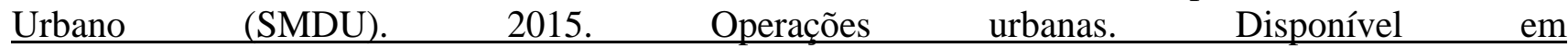
http://www.prefeitura.sp.gov.br/cidade/secretarias/desenvolvimento_urbano/sp_urbanismo/operacoes _urbanas/_Acesso em 25/03/2015]

SÃO PAULO (município). Operação urbana Água Branca. Lei municipal no 11.774, de 18/05/1995. Operação urbana Água Branca. Lei municipal no 15.893, de 7/11/2013. 